\title{
Consensus
}

Volume 30

Issue 1 Globalization

Article 19

5-1-2005

\section{Treasures old and new: images in the lectionary}

David Schnasa Jacobsen

Follow this and additional works at: http://scholars.wlu.ca/consensus

\section{Recommended Citation}

Jacobsen, David Schnasa (2005) "Treasures old and new: images in the lectionary," Consensus: Vol. 30 : Iss. 1 , Article 19. Available at: http://scholars.wlu.ca/consensus/vol30/iss1/19

This Book Reviews is brought to you for free and open access by Scholars Commons @ Laurier. It has been accepted for inclusion in Consensus by an authorized editor of Scholars Commons@ Laurier. For more information, please contact scholarscommons@wlu.ca. 
introduction that Lindbeck's writings in their entirety, and certainly those selected for this anthology, are interdependent and universally centred in a hope for Christian unity.

This anthology, as it has been edited and introduced, raises questions that are central to relationships within the wider Christian church. The majority of divisions within the wider Christian church are dependent upon doctrinal, political and theological disagreements from times that are not ours. Lindbeck suggests that a reconsideration of cultural and chronological boundaries could help to reconcile centuries of division. This suggestion is intended to encourage the reader to move beyond the theological and doctrinal categorization of his/her own denomination to reconsider each community's role in the movement towards unity.

Buckley has collected and effectively introduced key samples of the theological writings of George Lindbeck so that they might be available to theologians and, more generally, educated readers and students of religious studies. I would recommend this book for any person making an attempt to understand Christian relations, as well as any ordered or lay member of the wider Christian church who holds ecumenical relations central to his/her Christian identity.

W. S. Cranston

Department of Religion and Culture Wilfrid Laurier University

\section{Treasures Old and New: Images in the Lectionary Gail Ramshaw Minneapolis: Augsburg Fortress, 2002 435 pages. \$47.25 Hardcover}

In this book Gail Ramshaw weaves a wonderful tapestry of images from the three-year Revised Common Lectionary. She does so in a way that deepens our appreciation for the fabric of our lives as bounded by the proclamation of lectionary texts in Christian worship. In truth, what she develops is a marvelously deep and wondrous liturgical hermeneutic which takes the weft of the Bible seriously, but also sets it in the woof of the liturgical year and ongoing sacramental 
life. One cannot set down this book without a great appreciation for Ramshaw's gift. The images of the lectionary come alive on her pages and refuse to be kept captive to a distant past. Naturally, a few imperfections become apparent to even the most ardent admirers of her imagistic tapestry, yet even they fail to diminish significantly the reader's appreciation for her work.

The structure of the book is straightforward. An introduction and an afterword bookend the images she treats. The introduction helps readers understand the importance of the lectionary and the choices it makes (Ramshaw was the ELCA representative to the task force which developed the Revised Common Lectionary) as well as offering some theoretical underpinnings to explain why and how the images in lectionary texts are important. The afterword, though quite brief, allows you as the reader to frame and reflect back on the images she covers, inviting you poetically to dwell "... in the images, so that, after the liturgy, the images can be in you." (435)

The bulk of the book in the middle is made up of forty images. Naturally, the list is not exhaustive. However, the Biblical "forty" certainly gives the reader an appreciation for their breadth and power. Given Ramshaw's liturgical training, the reader is not surprised by many of the images chosen: body, clothing, cross, family, fire, journey, light, marriage, resurrection of the body, temple, water, and week. Ramshaw begins each image with a series of quotes, one from the Psalms to ground the image in the history of Israel's worship, one from a contemporary act of worship and/or hymn, and a few selected treatments of that image from important male and female figures in Church history. What follows over the next few pages is Ramshaw's own masterful interpretation of each image. Each treatment begins with an exploration of scriptural texts (cross-referenced with the corresponding lectionary pericope) and frequently includes a placement of that image within a broader history of religions or anthropological context. Inevitably, Ramshaw also wrestles theologically with each image.

Nonetheless, the discerning reader has more than just appreciation for Ramshaw's efforts. The primary treatment of the image of the Word of God, for example, occurs under two other headings: "Prophet" and "Emanation". Certainly the image of the Word for a Lutheran liturgical scholar deserves more treatment (and a more nuanced treatment in other parts of the book than its mere 
equation with the scriptures) than that. At points I also wished Ramshaw would have been a bit more critical with her take on the lectionary itself, especially its tendencies to reinscribe some problematic typological readings of Hebrew Bible texts, especially in Advent. Naturally the issue is not so much whether there should be some typological thinking, but how to do it in a way that honours both the lectionary tradition and Jewish-Christian relations.

Yet these concerns do not diminish substantially my appreciation for Ramshaw's work. Despite the flaws, preachers and worship planners alike will benefit from her beautify tapestry of lectionary images.

David Schnasa Jacobsen

Waterloo Lutheran Seminary

\section{The Angry Christian: A Theology for Care and Counseling} Andrew D. Lester

Louisville, Kentucky: Westminster John Knox Press, 2002

308 pages, $\$ 30.00$ Softcover

Andrew Lester is seeking to de-construct the notion of anger-as-sin and co-construct an alternative narrative about anger in the Christian tradition. The alternative narrative views anger as part of God's creation especially rooted in the commandment to love. Anger is not sin but can lead to sin. The terrible misuse of anger that leads to abuse and violence is sin. However, Lester does not want to throw the baby out with the bath water. He wants to affirm that anger is a healthy emotion and to find ways that the expression of anger can lead to life and not death. Lester argues that this alternative narrative is already present in Christianity but it is not the dominant narrative. The dominant narrative is that anger-is-sin and in this view, anger ought to be rooted out like rooting out weeds. In this book, the apt image for the alternative narrative about anger is that of a rose bush that needs to be pruned and gardened and not weeded out. Lester succeeds in presenting a strong argument for the alternative narrative

The book presents mostly a theological argument for seeing anger as part of God's creation, rooted in our biology and an outcome 